University of Nebraska - Lincoln

DigitalCommons@University of Nebraska - Lincoln

USDA National Wildlife Research Center - Staff Publications
U.S. Department of Agriculture: Animal and Plant Health Inspection Service

$1-1-2005$

\title{
Recent Population Status of the American White Pelican: A Continental Perspective
}

D. Tommy King

USDA/APHIS/WS National Wildlife Research Center, tommy.king@aphis.usda.gov

Daniel W. Anderson

University of California-Davis, dwanderson@ucdavis.edu

Follow this and additional works at: https://digitalcommons.unl.edu/icwdm_usdanwrc

Part of the Environmental Sciences Commons

King, D. Tommy and Anderson, Daniel W., "Recent Population Status of the American White Pelican: A Continental Perspective" (2005). USDA National Wildlife Research Center - Staff Publications. 40. https://digitalcommons.unl.edu/icwdm_usdanwrc/40

This Article is brought to you for free and open access by the U.S. Department of Agriculture: Animal and Plant Health Inspection Service at DigitalCommons@University of Nebraska - Lincoln. It has been accepted for inclusion in USDA National Wildlife Research Center - Staff Publications by an authorized administrator of DigitalCommons@University of Nebraska - Lincoln. 


\title{
Recent Population Status of the American White Pelican: A Continental Perspective
}

\author{
D. TOMMY KING ${ }^{1,3}$ AND DANIEL W. ANDERSON ${ }^{2,3}$ \\ ${ }^{1}$ USDA/WS National Wildlife Research Center, P.O. Box 6099, Mississippi State University, MS 39762 USA \\ Tommy.King@aphis.usda.gov \\ ${ }^{2}$ Department of Wildlife, Fish, and Conservation Biology, University of California, Davis, CA 95616 USA
}

${ }^{3}$ The names and affiliations of many individuals who provided colony information are cited in the appendix

\begin{abstract}
Breeding bird surveys were conducted at most American White Pelican (Pelecanus erythrorhynchos) colonies in North America from 1979-81 and the number of American White Pelicans was estimated at $>109,000$ breeding individuals in 55 colonies. Although many pelican colonies have not been surveyed since the early 1980s, we present the most current survey numbers available for North American colonies. Using available data (1998-2001) and the North American Continental Divide to delineate eastern from western metapopulations, 27 colonies and 48,240 nests in the East and 15 colonies and 18,790 nests in the West were documented, giving a total of about 134,000 breeding pelicans in North America. The nest numbers of 20 eastern and western colonies that were surveyed during 1979-81 and again in 1998-2001 were also compared to determine if pelican numbers are changing. The number of AWPE nests in those colonies has more than doubled since the 1979-81 surveys. Because current data for colonies in part of the United States and much of Canada are lacking and about 20 years have passed since more complete surveys were done, we propose that regular and coordinated North American pelican surveys should be initiated.
\end{abstract}

Key words.-American White Pelican, North America, Pelecanus erythrorhynchos, population status, surveys

Waterbirds 28 (Special Publication 1): 48-54, 2005

Independent nesting bird surveys were conducted at most of the American White Pelican (Pelecanus erythrorhynchos) colonies in North America from 1979-1981. Using these survey data, Sidle et al. (1985) estimated the total numbers of the American White Pelican (AWPE) at $>109,000$ breeding individuals in 55 colonies. Smith et al. (1984) and Paullin et al. (1988) noted a marked decrease in the number of colonies west of the North American Continental Divide from a historic high of 23-24 to 5-8 in 1984. During the same period, Sidle et al. (1985) reported that numbers were stable or increasing across the remainder of North America. No thorough, coordinated continental surveys have ever been conducted, and many breeding colonies have not been surveyed since the early 1980s (see notable exceptions in these proceedings: Madden and Restani 2005; Shuford 2005; Sovada et al. 2005; VanSpall et al. 2005). Because the status of many historic AWPE breeding colonies is not known, it is unclear if all are still active, if new breeding colonies have been established in other areas, or if numbers within these breeding colonies have increased or decreased.
Understanding the population status of the AWPE is necessary for developing effective management strategies to ensure healthy populations and to wisely manage human/ pelican interactions. For example, there is a need to develop strategies to reduce AWPE impacts on aquaculture in the southeastern United States (King 1997, 2005) and to effectively manage water levels for conservation (Moreno-Matiella and Anderson 2005; Murphy and Tracy 2005). In this paper, we present the most current (1998-2001) survey numbers available for AWPE colonies in North America and, where feasible, compare breeding colony nest numbers and trends from 1979-1981 to 1998-2001.

METHODS

Similar to Sidle et al. (1985), our numbers and locations of breeding colonies and nests were derived from specific surveys conducted by many individuals from 1998-2001. The nest estimates were doubled to obtain a breeding bird estimate. State and federal managers and other biologists working with the AWPE were contacted to obtain the latest survey data available for their regions (Appendix 1). The North American Continental Divide was used to delineate eastern and western breeding colonies and metapopulations (Evans and Knopf 
1993; Johnsgard 1993; Anderson and King 2005). The data were then compared with respect to eastern and western breeding colonies and in 1979-1981 and 19982001. Only data from the 20 breeding colonies surveyed during both periods were used in our comparisons of metapopulation trends. The use of only paired-data could represent a bias, because nearly all of the smaller western metapopulation was surveyed, whereas recent data for a portion of the eastern metapopulation could not be obtained. It is also important to note that the western metapopulation of the AWPE was already severely reduced from historical numbers (Smith et al. 1984; Paullin et al. 1988) prior to our recent comparisons. However, we were interested to determine if there were indications of a more recent increase or decline. Breeding colony locations and sizes were mapped using ArcView 3.2a (Environmental Systems Research Institute 2000). Breeding Bird Survey (BBS) data (Sauer et al. 2003) were also examined to obtain an independent evaluation of trends.

\section{RESULTS}

The locations and numbers of nests for 42 breeding colonies surveyed in North America from 1998-2001 (Fig. 1) were obtained. We were not able to obtain recent breeding colony data from Manitoba (except for Lake Winnipegosis), Saskatchewan, or Tamaulipas, Mexico. Twenty-eight $(66 \%)$ breeding colonies had $\leq 750$ nests. Chase Lake, North Dakota had the highest number of nests $(14,900)$ and was the largest single breeding colony in North America (Table 1; see also Sovada et al. 2005). Chase Lake was followed in abundance by Gunnison Island, Utah with 8,000 nests. Using 1998-2001 survey data, 67,000 AWPE nests were recorded in North America. If there are 134,000 breeding individuals and the assumption is made that $15 \%$ of the total numbers are nonbreeding birds (Lies and Behle 1966; Evans and Knopf 1993), we estimate the total numbers of the AWPE at over 157,000 individuals. Because the current status of many colonies surveyed during 1979-81 is not known and several other colonies were not surveyed during 1998-2001, our estimate is conservative for the time-period covered.

Using available data (1998-2001) and the North American Continental Divide to delineate eastern from western breeding colonies, 27 eastern breeding colonies with 48,240 nests and 15 western breeding colonies with 18,790 nests were identified (Fig. 2 ). The western metapopulation represent- ed $28 \%$ and the eastern metapopulation $72 \%$ of the numbers of breeding AWPE surveyed. The number of nests in the 20 breeding colonies surveyed in the eastern and western regions during 1979-81 and again in 1998-2001 have doubled since the 1979-81 surveys (Fig. 3).

U.S. Department of Interior Breeding Bird Survey data trends (Sauer et al. 2003) indicated that, overall, the total numbers of AWPE have increased by $4.8 \% \mathrm{yr}^{-1}$ (or about doubled) between 1980 and 2002, but it was not possible to precisely separate the two metapopulations. Looking specifically at the totals from our surveys using only our paired-data samples, the number of nests in the 20 colonies surveyed in the eastern and western regions at least doubled $(+106 \%)$ since the earlier surveys (Fig. 3), similar to the trend observed by Sauer et al. (2003).

\section{DISCUSSION}

Making meaningful comparisons between 1979-1981 and 1998-2001 data are difficult because several colonies surveyed during 1979-1981 have not been surveyed in recent years. Although recent data for all of the breeding colonies in North America were not acquired, the data presented indicate an increase in AWPE numbers throughout the areas surveyed, during the period that was examined. Similarly, the North American Breeding Bird Survey data show AWPE numbers increasing (Sauer et al. 2003).

The increase in the numbers of nesting birds in surveyed breeding colonies may have resulted from a number of factors. For example, the expansion of the aquaculture industry in the southeastern United States may have enhanced eastern metapopulation pelican winter-survivability by providing an abundant, readily available food source (King 1997, 2005; King and Grewe 2001). A possible link between aquaculture and the western AWPE metapopulation status remains untested, although aquaculture in western Mexico is known to be one of the fastest expanding industries in that region (Anderson et al. 2003), and the Salton Sea, with huge populations of introduced fish, 


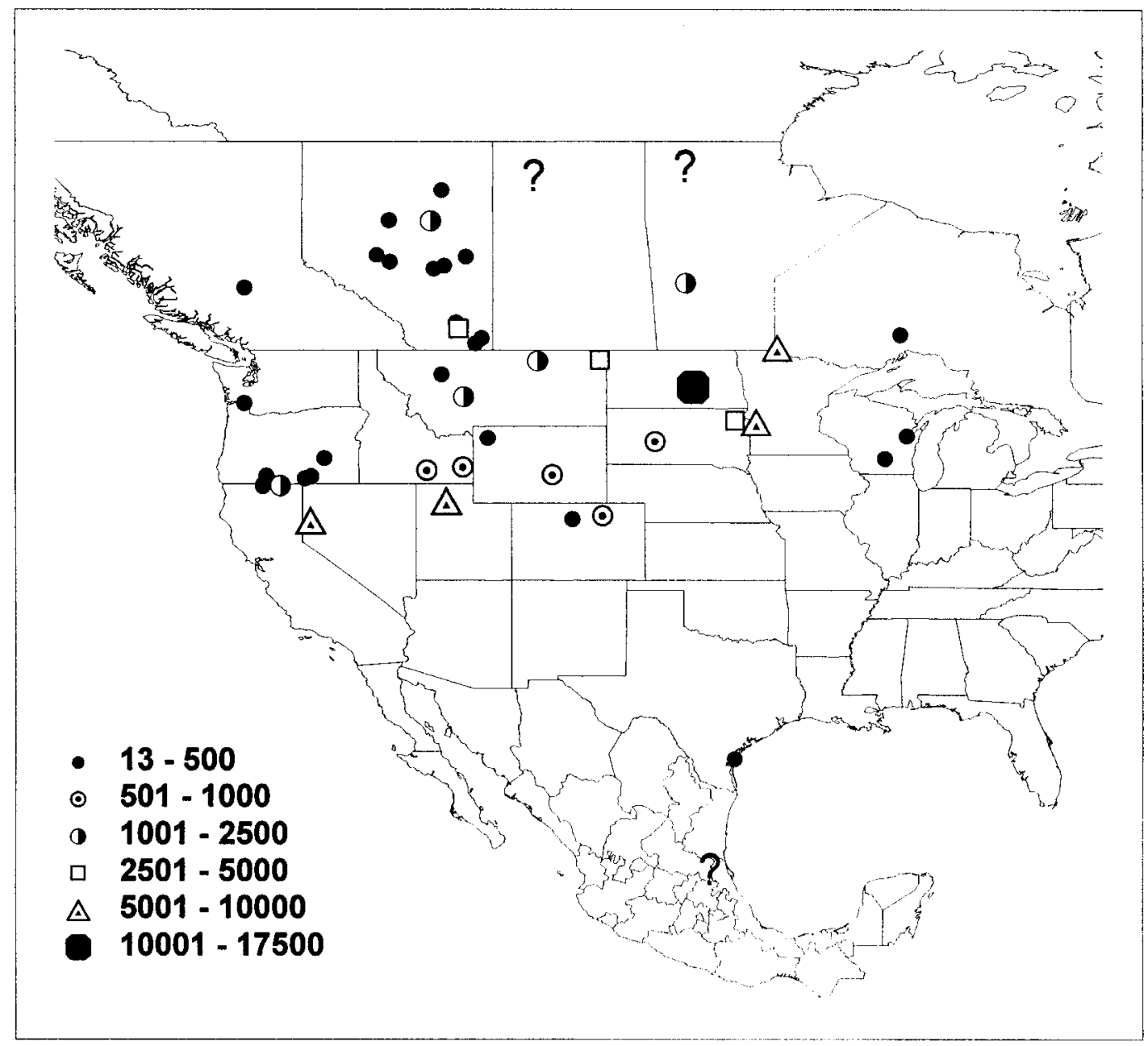

Figure 1. Locations of American White Pelican breeding colonies and their relative sizes, 1998-2001. Provinces and states with historic AWPE colonies but lacking recent data are identified with "?".

has become an important wintering and migratory-passage area for AWPE (Shuford and Molina 2004). Also, climate changes such as drought to wet periods may have positively affected AWPE numbers (Sovada et al. 2005).

The AWPE appears to be expanding its breeding range eastward with the recent establishment of new breeding colonies in Wisconsin (S. Matteson, pers. comm.). Because many historic AWPE breeding colonies have not been surveyed since the early 1980 s, it is unclear if these new breeding colonies were established as numbers increased or if some un-surveyed historic breeding colony sites became unsuitable for breeding AWPE resulting in colony relocation. Dynamic water levels throughout much of the AWPE breeding range may have caused the abandonment of some historic breeding colony sites leading to the establishment of new breeding efforts in areas with more viable resources. Although AWPE numbers were increasing in many parts of Canada and the United States into the early 1980s (Sidle et al. 1985), and still appear to be increasing in areas that were recently surveyed, the lack of current, continent-wide breeding colony and nesting numbers frustrates our efforts to reliably determine the current status of the AWPE throughout its breeding range. Additionally, information on the numbers of non-breeding and immature AWPE is lacking except 
Table 1. American White Pelican breeding colony locations, number of nests and year of survey in North America, 1998-2001.

\begin{tabular}{|c|c|c|c|c|}
\hline State/Province & Name & No. Nests ${ }^{\mathrm{b}}$ & Year & $1979-81^{\mathrm{d}}$ \\
\hline \multicolumn{5}{|l|}{ A. Eastern: ${ }^{\mathrm{a}}$} \\
\hline \multirow[t]{12}{*}{ Alberta } & Beaver Hill Lake & 150 & 1998 & 41 \\
\hline & Buffalo Lake & 300 & 1998 & \\
\hline & Chip Lake & 20 & 1998 & \\
\hline & Joseph Lake & 500 & 1998 & \\
\hline & Lake Newell & 20 & 1998 & \\
\hline & Lower Therien Lake & 50 & 1998 & \\
\hline & Namur Lake & 300 & 1998 & \\
\hline & Pakowki Lake & 50 & 1998 & 8 \\
\hline & Pelican Lake & 1,050 & 1998 & 216 \\
\hline & Hays Reservoir & 3,850 & 1998 & \\
\hline & St. Mary Reservoir & 80 & 1998 & \\
\hline & Utikuma Lake & 150 & 1998 & 165 \\
\hline \multirow[t]{3}{*}{ Colorado } & Antero Reservoir & $?^{c}$ & & \\
\hline & Arapaho NWR ${ }^{3}$ & 150 & 2001 & \\
\hline & Riverside Reservoir & 750 & 2001 & 500 \\
\hline \multirow[t]{2}{*}{ Manitoba } & Lake Winnipegosis & 2,500 & 1999 & 1,718 \\
\hline & Other areas & $?^{c}$ & & \\
\hline \multirow[t]{2}{*}{ Minnesota } & Marsh Lake WMA ${ }^{c}$ & 6,000 & 2001 & 961 \\
\hline & Lake of the Woods & 6,400 & 2001 & 275 \\
\hline \multirow[t]{2}{*}{ Montana } & Bowdoin NWR & 1,650 & 2000 & 1,192 \\
\hline & Medicine Lake NWR & 4,250 & 2001 & 1,600 \\
\hline North Dakota & Chase Lake NWR & 14,900 & 2001 & 6,142 \\
\hline Ontario & Lake Nipigon & 300 & 2001 & \\
\hline \multirow[t]{2}{*}{ South Dakota } & Bitter Lake & 3,000 & 2001 & \\
\hline & LaCreek NWR & 750 & 2001 & 1,900 \\
\hline Saskatchewan & & $?^{c}$ & & \\
\hline Tamaulipas & Laguna Madre & $?^{c}$ & & \\
\hline Texas & Laguna Madre & 200 & 2001 & \\
\hline \multirow[t]{2}{*}{ Wisconsin } & Cat Island & 200 & 1999 & \\
\hline & Horicon Marsh NWR & 20 & 1999 & \\
\hline Wyoming & Pathfinder Reservoir & 650 & 2001 & \\
\hline \multicolumn{5}{|l|}{ B. Western: ${ }^{\mathrm{a}}$} \\
\hline British Columbia & Stum Lake & 350 & 2001 & 120 \\
\hline \multirow[t]{2}{*}{ California } & Clear Lake NWR & 1,600 & 2001 & 1,571 \\
\hline & Lower Klamath NWR & 30 & 2001 & 750 \\
\hline \multirow[t]{2}{*}{ Idaho } & Blackfoot Reservoir & 800 & 2001 & \\
\hline & Minidoka NWR & 550 & 2001 & \\
\hline \multirow[t]{2}{*}{ Montana } & Arod Lake & 300 & 2001 & \\
\hline & Canyon Ferry & 1,800 & 2000 & \\
\hline Nevada & Anaho Island NWR & 3,950 & 2001 & 2,880 \\
\hline \multirow[t]{4}{*}{ Oregon } & Crump Lake & 200 & 2001 & 250 \\
\hline & Malheur NWR & 300 & 1998 & \\
\hline & Upper Klamath NWR & 260 & 2001 & 410 \\
\hline & Pelican Lake & 200 & 2001 & \\
\hline Utah & Gunnison Is. NWR & 8,000 & 2001 & 3,023 \\
\hline Washington & Columbia River & 150 & 1999 & \\
\hline Wyoming & Yellowstone Lake & 300 & 2001 & 285 \\
\hline Subtotal East & & 48,240 & & \\
\hline Subtotal West & & 18,790 & & \\
\hline Total & & 67,030 & & \\
\hline
\end{tabular}

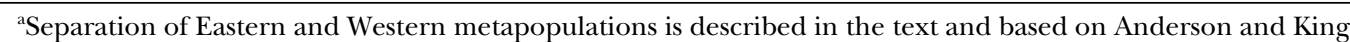
(2005).

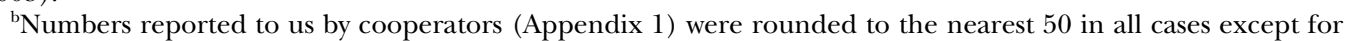
colonies reported as $<100$, which were rounded to the nearest 10 .

'Abbreviations: NWR = National Wildlife Refuge; WMA = a wildlife management area; Is. = Island; ? = no survey data.

${ }^{\mathrm{d}}$ Nest numbers reported in Sidle et al. 1985 used for comparison of population trend. 

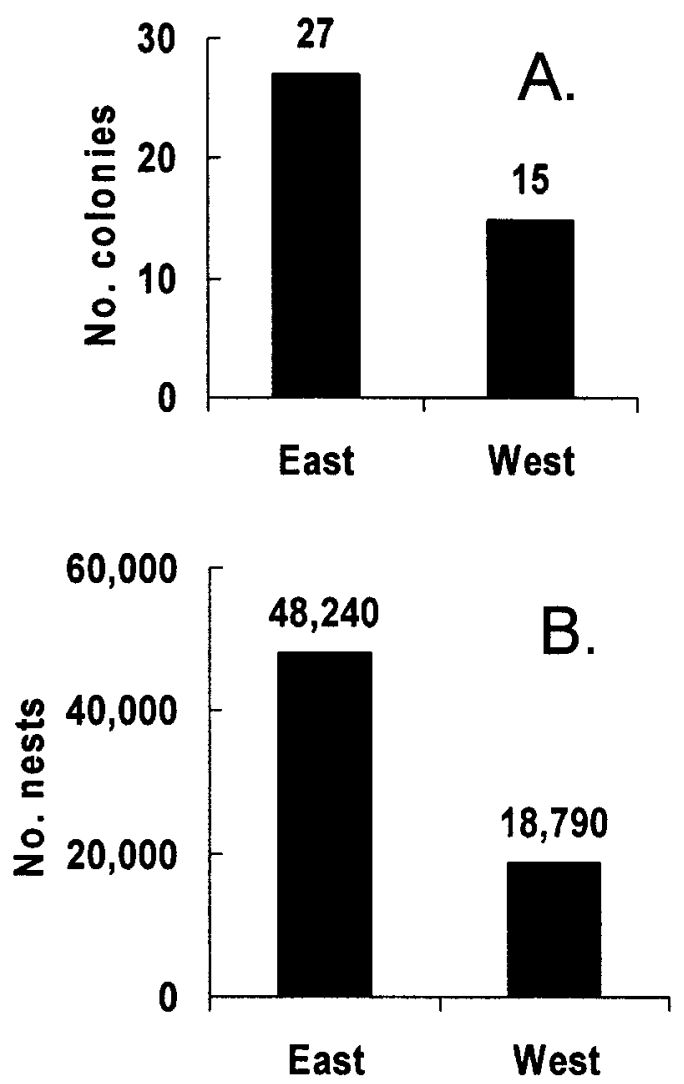

Figure 2. Numbers of American White Pelican breeding colonies and nests east and west of the North American Continental Divide, 1998-2001. Colonies without recent data were excluded.

for irregular observations of birds in typical wintering habitats during the summer months. Insufficient survey data for many breeding colonies and regions precludes development of a suitable breeding AWPE index and underscores the need for coordinated surveys to be initiated in the near future. These data may be combined with information on population dynamics, abundance, distribution and habits of non-breeding individuals, as part of an AWPE monitoring program. Sidle et al. (1985) recommended the establishment of a continental monitoring program for AWPE nearly 20 years ago. We echo their recommendation and urge all interested parties to work toward the establishment of a continental monitoring program. Further, we recommend a survey of all breeding colonies every

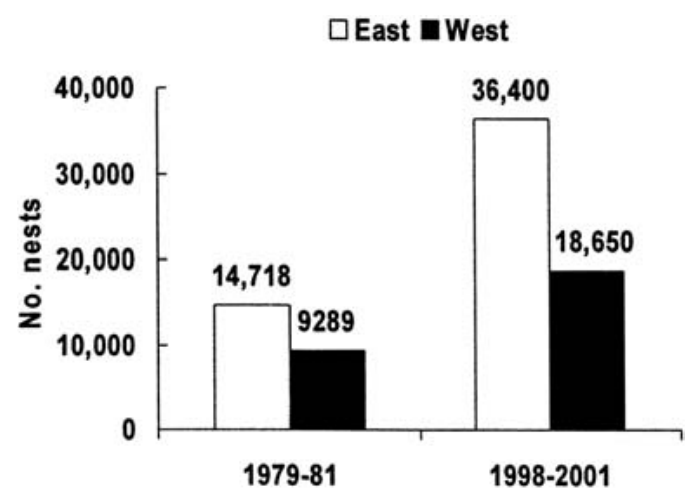

Figure 3. Comparison of American White Pelican nest numbers for 1979-81 vs. 1998-2001 and East vs. West of the North American Continental Divide. Only data from colonies surveyed during 1979-1981 and 1998-2001 were used $(\mathbf{N}=\mathbf{2 0})$.

10 years and we encourage managers to continue or establish annual breeding colony monitoring where feasible.

\section{ACKNOWLEDGMENTS}

We thank the many people who provided survey data and contact information for biologists monitoring pelicans in North America (Appendix 1). S. Barras, K. Godwin, G. Ivey, D. LeBlanc, D. Shuford and M. Tobin provided helpful comments on earlier drafts of this manuscript.

\section{LITERATURE CITED}

Anderson, D. W., E. Palacios, E. Mellink and C. ValdesCasillas. 2003. Migratory bird conservation and ecological health in the Colorado River Delta region. Pages 1091-1109 in D. J. Rapport, W. L. Lasley, D. E. Rolston, N. O. Nielsen, C. O. Qualset, and A. B. Damania (Eds.), Managing for Healthy Ecosystems. Lewis, Boca Raton, Florida.

Anderson, D. W. and D. T. King. 2005. Introduction: Biology and conservation of the American White Pelican. Waterbirds 28 (Special Publication 1): 1-8.

Evans, R. M. and F. L. Knopf. 1993. American White Pelican (Pelecanus erythrorhynchos). No. 57 in A. Poole and F. Gill (Eds.), The Birds of North America. The Academy of Natural Sciences, Philadelphia, and The American Ornithologists' Union, Washington, DC.

Johnsgard, P. A. 1993. Cormorants, darters, and pelicans of the world. Smithsonian Institution Press, Washington, DC.

King, D. T. 1997. American White Pelicans: The latest avian problem for catfish producers. Pages 31-35 in Proceedings Seventh Eastern Wildlife Damage Management Conference, Jackson, Mississippi, USA. 5-8 November 1995.

King, D. T. and A. H. Grewe, Jr. 2001. Movements and mortality of American white pelicans banded at 
Marsh Lake, Minnesota. North American Bird Bander 26: $57-60$.

King, D. T. 2005. Interactions between American White Pelicans and aquaculture in the southeastern United States: an overview. Waterbirds 28 (Special Publication 1): 83-86.

Lies, M. F. and W. H. Behle. 1966. Status of the White Pelican in the United States and Canada through 1964. Condor 68: 279-292.

Madden, E. M. and M. Restani. 2005. History and breeding ecology of the American White Pelican at Medicine Lake National Wildlife Refuge, Montana. Waterbirds 28 (Special Publication 1): 23-26.

Moreno-Matiella, L. A. and D. W. Anderson. 2005. Modeling water level variation and its effects on the availability of nesting habitat for the American White Pelican at Clear Lake National Wildlife Refuge, California. Waterbirds 28 (Special Publication 1): 73-82.

Paullin, D. G., G. L. Ivey and C. D. Littlefield. 1988. The re-establishment of American White Pelican nesting in the Malheur-Harney Lakes Basin, Oregon. Murrelet 69: 61-64.

Sauer, J. R., J. E. Hines and J. Fallon. 2003. The North American Breeding Bird Survey, Results and Analysis 1966-2002. Version 2003.1, USGS Patuxent Wild- life Research Center, Laurel, Maryland. http://www. mbr-pwrc.usgs.gov/cgi-bin/atlasr02.pl?SUR

Shuford, W. D. 2005. Historic and current status of the American White Pelican breeding in California. Waterbirds 28 (Special Publication 1): 35-47.

Shuford, W. D. and K. C. Molina (Eds.). 2004. Ecology and conservation of birds of the Salton Sink: an endangered ecosystem. Studies in Avian Biology 27: 1-169.

Sidle, J. G., W. H. Koonz and K. Roney. 1985. Status of the American White Pelican: an update. American Birds 39: 859-864.

Smith, M., T. Steinbach and G. Pampush. 1984. Distribution, foraging relationships and colony dynamics of the American White Pelican (Pelecanus erythrorhynchos) in southern Oregon and northeastern California. Natural Conservation, Portland, Oregon.

Sovada, M. A., D. T. King, M. Erickson and C. Gray. 2005. Historic and current status of the American White Pelican breeding at Chase Lake National Wildlife Refuge, North Dakota. Waterbirds 28 (Special Publication 1): 27-34.

VanSpall, K., J. Steciw and J. A. Young. 2005. Fifty years of American White Pelican Breeding at Stum Lake, British Columbia. Waterbirds 28 (Special Publication 1): 18-22.

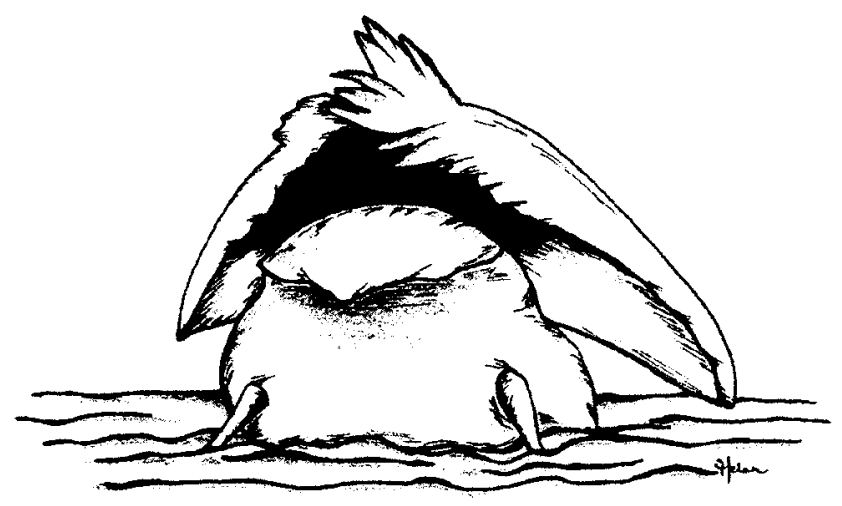


Appendix 1. American White Pelican survey co-operators' names and affiliations.

\begin{tabular}{|c|c|}
\hline Janice Anderson & Ministry of Water, Land and Air Protection, British Columbia \\
\hline Mike Artman & LaCreek NWR ${ }^{1}$, Martin, South Dakota \\
\hline John Beckstrand & Upper Klamath NWR, California \\
\hline Styron Bell & Anaho Island NWR, Nevada \\
\hline Gene Blaylock & Corpus Christi, Texas \\
\hline Steve Bouffard & Minidoka NWR, Idaho \\
\hline Howard Browers & Umatilla NWR, Washington \\
\hline Andrea Cerovski & Department of Game and Fish, Wyoming \\
\hline L. H. Dewey & Division of Wildlife Resources, Utah \\
\hline Jeff DiMateo & Department of Natural Resources, Minnesota \\
\hline Mick Erickson & Chase Lake NWR, Woodworth, North Dakota \\
\hline Paul Hendricks & Montana Natural Heritage Program, Missoula, Montana \\
\hline Gary Ivey & Malheur NWR, Oregon \\
\hline Gerry Kemp & Edmonton, Alberta \\
\hline Rolf Kraft & LaCreek NWR, Martin, South Dakota \\
\hline Bill Koonz & Dept. Natural Resources, Manitoba \\
\hline Doug Leschisin & Waubay NWR, South Dakota \\
\hline Rich Levad & Rocky Mountain Bird Observatory, Colorado \\
\hline Beth Madden & Medicine Lake NWR, Montana \\
\hline Scott Lockhart & Ministry of Natural Resources, Ontario \\
\hline Val Macins & Ministry of Natural Resources, Ontario \\
\hline A. E. Manning & Division of Wildlife Resources, Utah \\
\hline Summner Matteson & Department of Natural Resources, Wisconsin \\
\hline Dave Mauser & Upper Klamath NWR, California \\
\hline Wayne Nelson & Sustainable Resource Development, Alberta \\
\hline Kit Novick & Department of Fish and Game, California \\
\hline Don Paul & Division of Wildlife Resources, Utah \\
\hline Diane Penttila & Horicon Marsh NWR, Wisconsin \\
\hline Kory Richardson & USFWS Valley City Wetland Mgmt. District, North Dakota \\
\hline Keith Roney & Royal Museum, Regina, Saskatchewan \\
\hline Ron Ryder & Colorado State University, Colorado \\
\hline Bill Shultz & Sand Lake NWR, South Dakota \\
\hline Julie Steciw & Ministry of Water, Land and Air Protection, British Columbia \\
\hline Martin St. Louis & Dept. of Fish and Game, Oregon \\
\hline Rob Swanison & Ministry of Natural Resources, Ontario \\
\hline Katharine VanSpall & Ministry of Water, Land and Air Protection, British Columbia \\
\hline Martha Wackenhut & Department of Fish and Game, Idaho \\
\hline Donna Withers & Anaho Island NWR, Nevada \\
\hline
\end{tabular}

\footnotetext{
${ }^{1} \mathrm{NWR}=$ National Wildlife Refuge.
} 